\title{
CHANGES IN THE GLYCOPROTEIN COMPOSITION OF PLASMA MEMBRANE DURING THE DIFFERENTIATION OF FRIEND ERYTHROLEUKEMIA CELLS
}

\author{
GIELJAN J.C.G.M. BOSMAN, PIETER BOER * and ELIZABETH P. STEYN-PARVE \\ Laboratory for Physiological Chemistry, State University of Utrecht, Vondellaan 24 A, 3521 GG Utrecht (The Netherlands)
}

(Received May 27th, 1982)

Key words: Differentiation; Plasma membrane; Glycoprotein; (Friend erythroleukemia cells)

Friend erythroleukemia cells display transient and permanent changes in the composition of their plasma membrane-bound glycoproteins during dimethyl sulfoxide-induced differentiation. The transient changes, as revealed by metabolic labeling with $\left.\mid{ }^{14} \mathrm{C}\right]$ glucosamine, are most conspicuous around the time during which most cells become committed to terminal differentiation. Permanent changes are revealed by reductive tritiation after oxidation with $\mathrm{NaIO}_{4}$ or galactose oxidase. In differentiated cells one glycoprotein fraction $\left(M_{r} 150000\right)$ could not be labeled by any of these methods, although it does contain neuraminic acid. We found no evidence in support of the hypothesis that the anomalous behavior of this fraction is caused by an increased degree of $\boldsymbol{O}$-acetylated neuraminic acid in the plasma membrane of differentiated cells.

\section{Introduction}

Friend virus-transformed murine erythroleukemia cells provide a valuable model for the study of erythroid cell differentiation. They form a homogeneous population of proerythroblast-like cells that can be induced to differentiate to a normoblast stage by dimethyl sulfoxide (DMSO) and a variety of other agents. During this differentiation the cells undergo a series of changes also seen during normal erythropoiesis, e.g., the start of hemoglobin synthesis during the terminal cell divisions (for a review see Ref. 1).

These changes also include alterations in the synthesis of some erythrocyte membrane proteins [2-4] and erythrocyte-specific antigens [5,6]. Studies of lectin binding and agglutinability also reveal the occurrence of - less well defined - changes in membrane architecture $[7,8]$.

These alterations may be correlated with

\footnotetext{
* To whom correspondence should be addressed.
}

changes in the glycprotein composition of the plasma membrane. Some changes in the synthesis of membrane glycoproteins have been described $[9,10]$ or can be deducted from observations on sialic acid synthesis [11] and glycosyltransferase activities [12]. As membrane glycoproteins are involved in a variety of physiological processes (for a review see Ref. 13) changes in glycoprotein synthesis may also be related to the changing cellular requirements during the differentiation of the Friend cell. This idea is supported by the differentiation-inhibiting properties of some inhibitors of protein glycosylation [14].

To gain further insight into the structural and functional properties of these membrane glycoproteins, we have analyzed some of the changes in their composition during the DMSO-induced differentiation of the Friend erythroleukemia cell.

Materials and Methods

Friend erythroleukemia cells (cell line GM-86, clone 745 ) were cultured and induced to differenti- 
ate by DMSO (Merck) as described before [14]. Cultures were synchronized by isoleucine deprivation [15].

Metabolic labeling was performed with $5 \mu \mathrm{Ci}$ D-[U- $\left.{ }^{14} \mathrm{C}\right]$ glucosamine $(254 \mathrm{mCi} / \mathrm{mmol}$, Amersham International) for $8 \mathrm{~h}$ or with $20 \mu \mathrm{Ci} \mathrm{N}$ $\left[{ }^{3} \mathrm{H}\right]$ acetyl-D-mannosamine (ManNAc, $500 \mathrm{mCi}$ / mmol, Amersham International) for $16 \mathrm{~h}$ in $25 \mathrm{ml}$ of culture medium.

To label sialoglycoproteins, cells were oxidized with $\mathrm{NaIO}_{4}$ followed by reduction with $\mathrm{NaB}^{3} \mathrm{H}_{4}$ (5-10 Ci/mmol, I.R.E.) according to Gahmberg and Andersson [16]. Alternatively, cells were labeled with $\mathrm{NaB}^{3} \mathrm{H}_{4}$ after oxidation of external galactose and $\mathrm{N}$-acetylgalactosamine residues with galactose oxidase $\left(10 \mathrm{U} / 2 \cdot 10^{7}\right.$ cells per $\left.\mathrm{ml}\right)$ from Dactylium dendroides (Sigma) according to Gahmberg and Hakomori [17]. To remove external neuraminic acid residues, the cells were incubated with neuraminidase $\left(5 \mathrm{U} / 2 \cdot 10^{7}\right.$ cells per $\left.\mathrm{ml}\right)$ from Vibrio cholerae (Calbiochem-Behring Corp.) preceding oxidation with galactose oxidase.

The plasma membrane fraction of $4 \cdot 10^{7}$ cells was isolated on a discontinuous sucrose gradient [18] and analyzed by electrophoresis on sodium dodecyl sulfate polyacrylamide gels [19]. After electrophoresis the gels were frozen and sliced. Radioactivity was measured after extracting the slices in 10\% Soluene-350 (Packard) in Lipoluma (Baker).

Sialic acid isolation and analysis were performed by standard techniques [20]. Briefly, a plasma membrane fraction of cells labelled with $\left[{ }^{3} \mathrm{H}\right] \mathrm{ManNAc}$ was subjected to mild acid hydrolysis (pH 2-3, $60 \mathrm{~min}$ at $\left.60^{\circ} \mathrm{C}\right)$ followed by extensive dialysis. Hydrolysis was repeated in $0.1 \mathrm{M}$ $\mathrm{HCl}$ for $60 \mathrm{~min}$ at $80^{\circ} \mathrm{C}$ and dialysis was performed accordingly. The dialysates were combined and purified by ion-exchange chromatography [20]. Sialic acids were analyzed by thin-layer chromatography on $0.2 \mathrm{~mm}$ cellulose plastic sheets (Merck) using the solvent system $n$-butanol $/ n$-propanol $/ 0.1 \mathrm{M} \mathrm{HCl}(1: 2: 1, \mathrm{v} / \mathrm{v})$. The plates were prerun in $0.1 \mathrm{M} \mathrm{HCl}$ just before use. $N$-[4$\left.{ }^{14} \mathrm{C}\right]$ Acetylneuraminic acid $(56.8 \mathrm{mCi} / \mathrm{mmol}$, New England Nuclear) was used as a reference compound. After development the plates were dried, cut into slices and counted in Instagel (Packard) after extraction in water.
Determination of the sialic acid content of the plasma membrane fraction and estimation of the degree of $\mathrm{O}$-acetylation was performed with the fluorimetric method of Shukla and Schauer [22].

Hydrocortisone was from Sigma and tunicamycin was a gift from Dr. G. Tamura (Tokyo). All chemicals were analytical grade.

\section{Results}

When the cells were synchronized by isoleucine deprivation with the method of Ley and Tobey [15], control and DMSO-treated cells grew synchronously for three cell generations in almost $50 \mathrm{~h}$ (Fig. 1). After this period, synchronization was lost, which is in agreement with earlier observations [23].

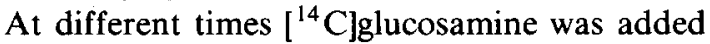
to the medium of synchronized cells. $8 \mathrm{~h}$ later the cells were harvested and their plasma membranes were analyzed by gel electrophoresis. As shown in Fig. 2, there are only slight differences between the radioactivity pattern of control cells labeled from 42 to $50 \mathrm{~h}$ after the start of the culture (Fig. 2A) and the pattern of fully differentiated cells (Fig. $2 \mathrm{D})$. The same pattern as shown in Fig. $2 \mathrm{~A}$ was observed when control cells were labeled during other periods or when control and fully differentiated cells were labeled with other radioactive sugars such as fucose, galactose and mannose (data not shown). However, differentiating cells labeled after the first (Fig. 2B) and second (Fig. 2C) division

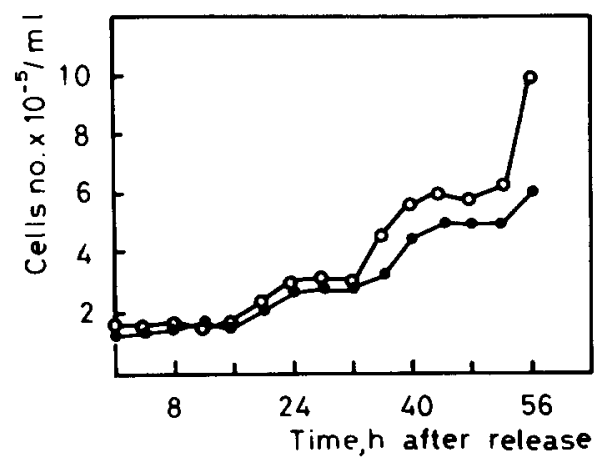

Fig. 1. Synchronization of Friend cells by isoleucine deprivation. Logarithmically growing cells were kept in medium without isoleucine for $40 \mathrm{~h}$. Cells were released by seeding into medium containing isoleucine with (e) or without (O) DMSO. 


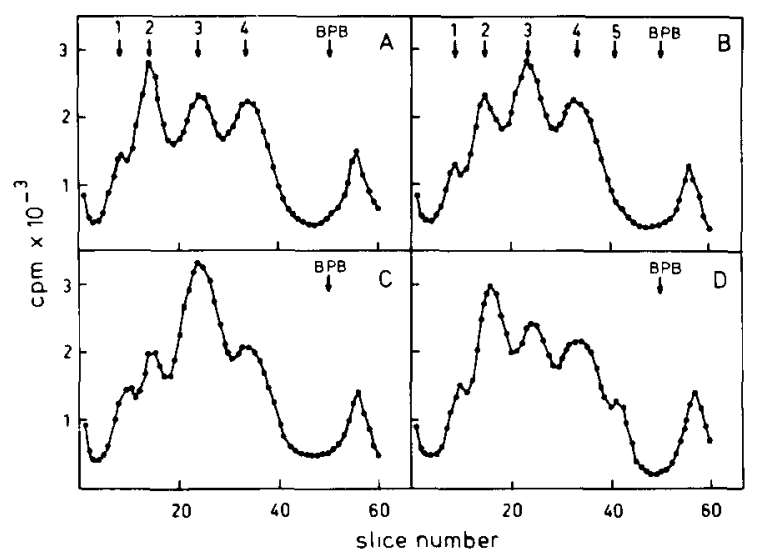

Fig. 2. Sodium dodecyl sulfate gel electrophoresis patterns of Friend cell plasma membranes labeled with $\left[{ }^{14} \mathrm{C}\right]$ glucosamine. $A$, undifferentiated cells labeled from 42 to $50 \mathrm{~h}$ after the start of the culture; B,C, differentiating cells labeled from 24 to $32 \mathrm{~h}$ (B) and from 42 to $50 \mathrm{~h}$ (C) after the addition of DMSO; D, differentiated cells labeled from 88 to $96 \mathrm{~h}$ after the addition of DMSO. BPB: Bromophenol blue marker dye.

display a different pattern of incorporation of $\left[{ }^{14} \mathrm{C}\right]$ glucosamine into the glycoproteins of their plasma membranes. This difference is most conspicuous in cells labeled from 42 to $50 \mathrm{~h}$ after the addition of DMSO (Fig. 2C). During this period radioactivity seems to be preferentially incorporated into the glycoprotein designated band 3 .

Experiments with inhibitors of the differentiation indicate that the pattern shown in Fig. $2 \mathrm{C}$ is specific for Friend cells at this stage of DMSO-induced differentiation. Hydrocortisone inhibits the differentiation in a way not yet elucidated [24]. The glycoprotein pattern of cells cultured in the simultaneous presence of DMSO and hydrocortisone (Fig. 3A) is similar to the pattern of cells cultured with hydrocortisone alone (data not shown) or undifferentiated cells (Fig. 2A).

Tunicamycin, a specific inhibitor of protein glycosylation, inhibits the differentiation by interfering with the process that leads the cells to become irreversibly committed to terminal differentiation [14]. The pattern of cells grown in the simultaneous presence of DMSO and tunicamycin for $96 \mathrm{~h}$ (Fig. 3B) closely resembles the pattern of cells labeled from 42 to $50 \mathrm{~h}$ after the addition of DMSO alone (Fig. 2C). Treatment with tunicamycin alone produces the pattern of undifferen-

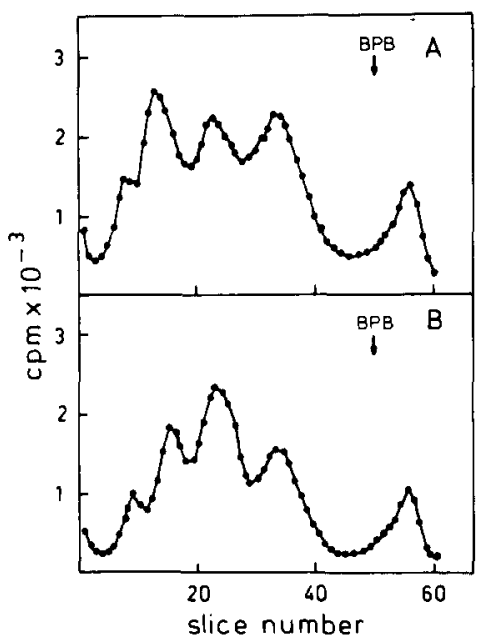

Fig. 3. The effect of inhibitors of the differentiation on the electrophoresis pattern of Friend cell plasma membranes labeled with $\left[{ }^{14} \mathrm{C}\right]$ glucosamine. A, cells labeled from 88 to $96 \mathrm{~h}$ after the simultaneous addition of DMSO and $1 \cdot 10^{-6} \mathrm{M}$ hydrocortisone; B, cells labeled from 88 to $96 \mathrm{~h}$ after the simultaneous addition of DMSO and $0.05 \mu \mathrm{g} / \mathrm{ml}$ tunicamycin.

tiated cells (pattern not shown, cf. Fig. 2A).

In contrast to the transient changes revealed by incorporation of $\left[{ }^{14} \mathrm{C}\right]$ glucosamine, permanent changes in the glycoprotein composition of the plasma membrane between undifferentiated and fully differentiated Friend cells are detected when the cells are labeled in their sialic acid residues with $\mathrm{NaB}^{3} \mathrm{H}_{4}$ after oxidation with $\mathrm{NaIO}_{4}$ [16]. In undifferentiated cells the same glycoproteins that are labeled with $\left[{ }^{14} \mathrm{C}\right]$ glucosamine are labeled with the $\mathrm{NaIO}_{4} / \mathrm{NaB}^{3} \mathrm{H}_{4}$ method (Fig. 4A). The plasma membrane glycoproteins of fully differentiated cells labelled $96 \mathrm{~h}$ after the addition of DMSO, however, display a different pattern (Fig. 4B). A new glycoprotein (band 5) becomes visible, and there is an increased incorporation of radioactivity into band 4 . The most notable difference, however, is the apparent disappearance of sialic acid from band 2. Cells labeled after 2 days in the presence of DMSO display a pattern intermediate between undifferentiated and fully differentiated cells (results not shown).

Labeling of the membrane glycoproteins in their external galactose and $N$-acetylgalactosamine residues with $\mathrm{NaB}^{3} \mathrm{H}_{4}$ after oxidation with galactose oxidase [17] resulted in the patterns of Fig. $4 \mathrm{C}$ for 


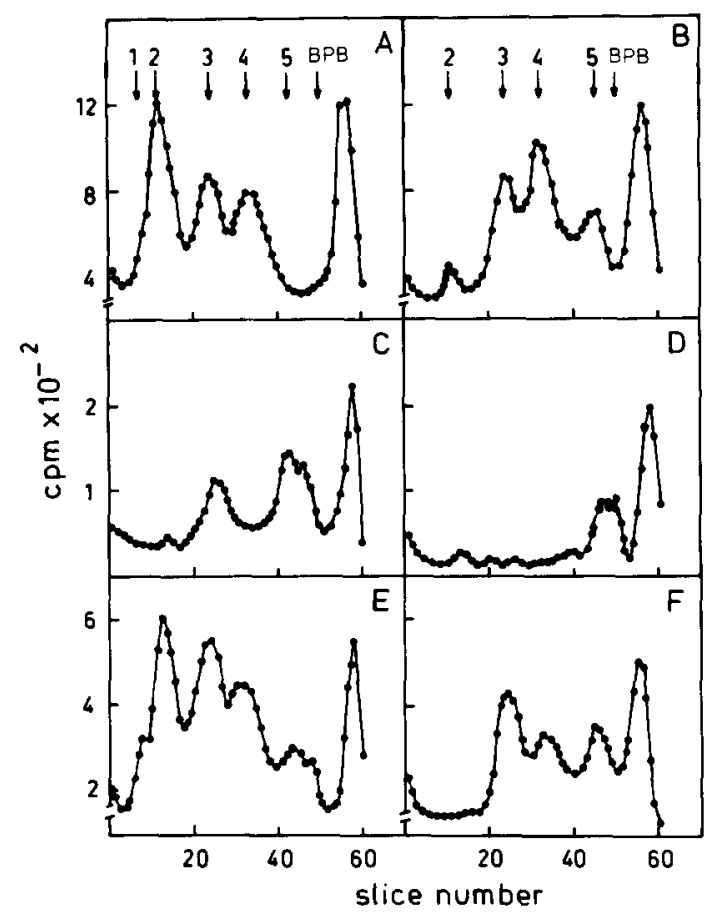

Fig. 4. Sodium dodecyl sulfate gel electrophoresis patterns of Friend cell plasma membranes labeled by reductive tritiation after $96 \mathrm{~h}$ in culture. A,B, undifferentiated (A) and differentiated (B) cells labeled with $\mathrm{NaIO}_{4} / \mathrm{NaB}^{3} \mathrm{H}_{4} ; \mathrm{C}, \mathrm{D}$, undifferentiated (C) and differentiated (D) cells labeled with galactose oxidase $/ \mathrm{NaB}^{3} \mathrm{H}_{4} ; E, F$, undifferentiated (E) and differentiated (F) cells labeled with galactose oxidase $/ \mathrm{NaB}^{3} \mathrm{H}_{4}$ after treatment with neuraminidase.

\section{TABLE I}

CHANGES IN THE PLASMA MEMBRANE GLYCOPROTEINS DURING THE DIFFERENTIATION OF FRIEND CELLS

A comparison of the plasma membrane electrophoresis patterns of control (C) and differentiated (D) Friend cells labeled with $\mathrm{NaB}^{3} \mathrm{H}_{4}$ after oxidation with $\mathrm{NaIO}_{4}$, galactose oxidase (Gal.ox.) and galactose oxidase following neuraminidase treatment (Gal.ox./Nase) after $96 \mathrm{~h}$ in culture. The numbers in parentheses refer to the arrows in Fig. 4. + , incorporation of label; - no incorporation of label.

\begin{tabular}{lllllll}
\hline $\begin{array}{l}\text { Apparent } \\
M_{\mathbf{r}}\left(\times 10^{-3}\right)\end{array}$ & $\mathrm{NaIO}_{4}$ & & Gal.ox. & \multicolumn{2}{l}{$\begin{array}{l}\text { Gal.ox./ } \\
\text { Nase }\end{array}$} \\
\cline { 2 - 6 } & C & D & C & D & C & D \\
\hline $150(2)$ & + & - & - & - & + & - \\
$105(3)$ & + & + & + & - & + & + \\
$85(4)$ & + & + & - & - & + & + \\
$45(5)$ & - & + & + & + & + & + \\
\hline
\end{tabular}

undifferentiated and Fig. 4D for differentiated cells. Now in undifferentiated cells band 5 also becomes visible, while the glycoprotein designated band 3 is labeled in undifferentiated cells only. It should be noted that the band 2 glycoprotein cannot be labeled with this method in undifferentiated or in differentiated cells.

In undifferentiated cells, all plasma membrane glycoproteins can be labeled with the galactose oxidase $/ \mathrm{NaB}^{3} \mathrm{H}_{4}$ method after treatment of the cells with neuraminidase as described in Materials and Methods (Fig. 4E). The same holds for the glycoproteins of differentiated cells with one exception: the glycoprotein designated band 2 (Fig. $4 \mathrm{~F}$ ). The results of these three labeling methods are summarized in Table $\mathrm{I}$.

From these results it can be concluded that during the differentiation of Friend cells permanent changes occur in the terminal carbohydrate composition of their plasma membrane glycoproteins. The most conspicuous changes occur in the glycoprotein designated band 2 . In differentiated cells this fraction can no longer be labeled with any of the methods used that are specific for ultimate sialic acid or (pen)ultimate galactose residues (Fig. 4).

To explain the anomalous behavior of this band 2 we hypothesized that during differentiation the sialic acid of this glycoprotein might become acetylated in its polyhydroxy side-chain. The sialic acid of the mature mouse erythrocyte has been reported to be heavily acetylated [21,22], which makes it resistant to oxidation with $\mathrm{NaIO}_{4}$ [25] and less susceptible to neuraminidase [26]. To test this hypothesis we labeled undifferentiated and differentiated cells with the galactose oxidase/ $\mathrm{NaB}^{3} \mathrm{H}_{4}$ method after an incubation with neuraminidase at a concentration $(50 \mathrm{U} / \mathrm{ml}) 10$-fold that used in the normal procedure. After gel electrophoresis of the plasma membrane fractions, however, we observed the same radioactivity patterns as obtained with the normal neuraminidase concentration (Figs. 4E and 4F). In another approach to test this hypothesis we labeled the cells metabolically with $\left[{ }^{3} \mathrm{H}\right] \mathrm{ManNAc}$ as a direct precursor of sialic acids [27]. Fig. 5 shows that there is no difference between undifferentiated and differentiated cells in the incorporation of this sugar into the various glycoproteins, although less radio- 
activity is incorporated into the total plasma membrane fraction of differentiated cells. Plasma membranes thus labeled with $\left[{ }^{3} \mathrm{H}\right]$ ManNAc were also subjected to mild acid hydrolysis using a method which specifically releases sialic acid and causes the least possible loss of $O$-acetylated residues (Ref. 19, see Materials and Methods). With this method about $70 \%$ of the radioactivity is found to cochromatograph on thin-layer chromatography with authentic $N-\left[{ }^{14} \mathrm{C}\right]$ acetylneuraminic acid (Neu5Ac). Only $10 \%$ has a $R_{\mathrm{F}}$ value of 1.37 relative to Neu5Ac, corresponding to the relative $R_{\mathrm{F}}$ value of mono- $O$-acetylated Neu5Ac. These figures are the same for the membrane glycoproteins of undifferentiated and differentiated cells (Fig. 6).

When, after gel electrophoresis of $\left[{ }^{3} \mathrm{H}\right] \mathrm{Man}$ NAc-labeled plasma membranes of undifferentiated and fully differentiated cells, the band 2 fraction was eluted from the gel according to Hager and Burgess [28], essentially the same results were obtained (data not shown).

The results indicate that during the differentiation of the Friend cell there is no increase in the

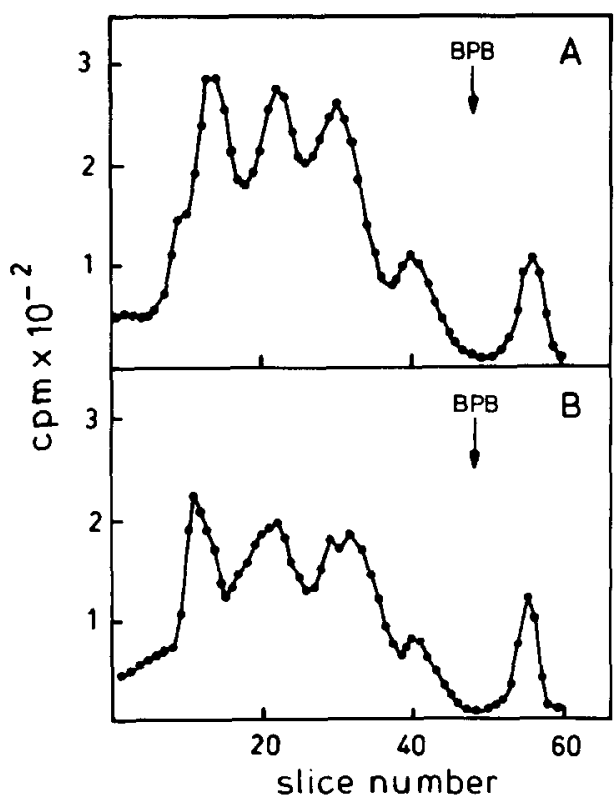

Fig. 5. Sodium dodecyl sulfate gel electrophoresis patterns of Friend cell plasma membranes labelled with $N-\left[{ }^{3} \mathrm{H}\right]$ acetyl-Dmannosamine. A, undifferentiated cells labeled from 80 to $96 \mathrm{~h}$ after the start of the culture; B, differentiated cells labeled from 80 to $96 \mathrm{~h}$ after the addition of DMSO.

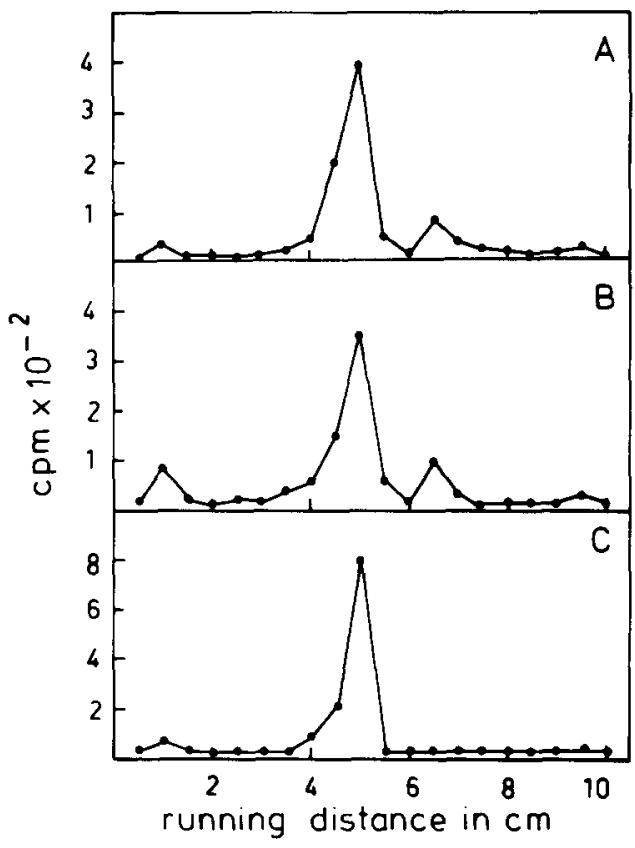

Fig. 6. Thin-layer chromatography of the neuraminic acid fraction of Friend cell plasma membranes labeled with $N$. $\left[{ }^{3} \mathrm{H}\right]$ acetyl-D-mannosamine from 80 to $96 \mathrm{~h}$ after the start of the culture. A, undifferentiated cells; B, differentiated cells; $\mathrm{C}$, reference compound: $N-\left[4-{ }^{14} \mathrm{C}\right]$ acetylneuraminic acid.

fraction of $O$-acetylated neuraminic acid of the plasma membrane glycoproteins, nor is there an increased $O$-acetylation in the neuraminic acid of one glycoprotein (band 2) in differentiated cells. This conclusion is confirmed by a direct estimation of the degree of $O$-acetylation in the plasma membrane-bound neuraminic acid using the fluorimetric method of Shukla and Schauer [22]. With this method, which makes use of the increase of fluorescence after de- $O$-acetylation by $0.1 \mathrm{M}$ alkali treatment, no significant differences were observed in the amount of sialic acid $(50 \mu \mathrm{g} / \mathrm{mg}$ protein) nor in the degree of $O$-acetylation (20-25\%) between the plasma membrane fractions of differentiated and undifferentiated cells.

\section{Discussion}

In the present study we describe some changes in the glycoprotein composition of the plasma membrane during the DMSO-induced differentia- 
tion of Friend erythroleukemia cells from a proerythroblast to a normoblast-like stage.

Transient changes are revealed by metabolic labeling of the glycoproteins with $\left[{ }^{14} \mathrm{C}\right]$ glucosamine. These changes are most conspicuous during the 2 nd day after the addition of DMSO. Preliminary experiments with lectin-affinity chromatography suggest that they coincide with a temporary decrease in the affinity of some glycoproteins (band 2, Fig. 2) towards wheat-germ lectin.

Although the structural nature of these changes remains to be elucidated, the use of cells that grew synchronously during the time of labeling (Fig. 1) and the results of experiments with hydrocortisone and tunicamycin (Fig. 3) indicate that the observed glycoprotein pattern is specific for Friend cells that have been cultured with DMSO for about $48 \mathrm{~h}$. At this time, most of the cells become irreversibly committed to terminal differentiation $[14,29]$. It is noteworthy that treatment with tunicamycin, which inhibits the differentiation by inhibiting the cells from becoming committed [14], results in the same glycoprotein pattern (Fig. 3B). This provides further indications implicating a functional relation between the synthesis and/or glycosylation of membrane glycoproteins and the differentiation process.

In contrast to these transient changes, permanent changes after differentiation are detected when the glycoproteins are labeled by reductive tritiation with $\mathrm{NaB}^{3} \mathrm{H}_{4}$ after oxidation with $\mathrm{NaIO}_{4}$ and galactose oxidase with or without a preceding neuraminidase treatment (Fig. 4). A comparison of the results obtained with these methods (Table I) shows that most of these changes may be related to alterations in the carbohydrate composition that include the addition or loss of neuraminic acid residues. Such an assumption, however, cannot explain the observation that the band 2 glycoprotein of differentiated cells cannot be labelled by these methods. The results from experiments in which the glycoproteins were labeled metabolically with radioactive sugars such as galactose, mannose, glucosamine (Fig. 2) and $N$-acetylmannosamine (Fig. 5) indicate that this band 2 glycoprotein is being synthesized in differentiated cells. Furthermore, they provide no indications for changes in the carbohydrate part of this fraction that could explain its resistance towards the methods to label ultimate sialic acid and (pen)ultimate galactose residues (Fig. 4). Therefore, we examined the possibility that the neuraminic acid of this fraction might become acetylated in its polyhydroxy side-chain during the differentiation. An increased acetylation could account for an increased resistance towards oxidation with $\mathrm{NaIO}_{4}$ [25] or release by neuraminidase [26]. Also it has been reported that $9 . O$-acetyl-Neu5Ac is the almost exclusive sialic acid in mature mouse erythrocytes $[21,30]$. However, we found no evidence in support of this idea.

Increasing the concentration of neuraminidase prior to galactose oxidase $/ \mathrm{NaB}^{3} \mathrm{H}_{4}$ treatment did not result in the labeling of this band 2 glycoprotein of differentiated cells. Although $\left[{ }^{3} \mathrm{H}\right] \mathrm{ManNAc}$ is incorporated into this fraction as neuraminic acid to the same amount in differentiated as it is in undifferentiated cells (Fig. 5), only a small percentage $(\max .15 \%)$ is incorporated into $9-\mathrm{O}$ acetyl-Neu5Ac (Fig. 6). Furthermore, analysis of the plasma membrane-bound neuraminic acid with a direct and specific method [22] did not reveal any increase of 9-O-acetyl-NeuSAc in the plasma membrane of differentiated cells. Altogether, these observations provide no evidence for an increased acetylation of the neuraminic acid of the differentiated Friend cells, which leaves us without an explanation for the anomalous behavior of the band 2 glycoprotein in differentiated Friend cells.

Further insight into the transient and permanent changes described in this study may be provided by structural analysis. Work is now in progress to purify the plasma membrane-bound glycoproteins of the Friend erythroleukemia cell at different stages during its differentiation in order to analyze their carbohydrate composition.

\section{Acknowledgements}

We gratefully acknowledge the expert technical assistance of Miss W. van den Herik. We also thank Drs. R. Schauer and A.K. Shukla (Kiel, F.R.G.) for helpful discussions and Dr. A.K. Shukla for performing the $O$-acetylneuraminic acid determinations. 


\section{References}

1 Reuben, R.C., Rifkind, R.A. and Marks, P.A. (1980) Biochim. Biophys. Acta 605, 325-346

2 Eisen, H., Bach, R. and Emery, R. (1977) Proc. Natl. Acad. Sci. U.S.A. 74, 3898-3902

$3 \mathrm{Hu}$, H.Y., Gardner, J, and Aisen, P. (1977) Science 197 559-561

4 Sabban, E.L., Sabatini, D.D., Marchesi, V.T. and Adesnik, M.A. (1980) J. Cell. Physiol. 104, 261-268

5 Fujinami, N., Sugimoto, Y. and Hagiwara, A. (1973) Dev. Growth Differ. 15, 141-151

6 Pfeffer, S.R. and Redman, C.M. (1981) Biochim. Biophys. Acta 641, 254-263

7 Eisen, H., Nasi, S., Georgopoulos, C.P., Arndt-Jovin, D. and Ostertag, W. (1977) Cell 10, 689-695

8 Tsiftsoglou, A.S. and Sartorelli, A.C. (1981) Biochim. Biophys. Acta $649,105-112$

9 Bosman, G.J.C.G.M. and Boer, P. (1979) Glycoconjugates, Proceedings of the 5th International Symposium (Schauer, R., Boer, P., Buddecke, E., Kramer, M.F., Vliegenthart, J.F.G. and Wiegandt, H., eds.), pp. 595-596, Thieme, Stuttgart

10 Gazitt, Y. and Friend, C. (1981) Cancer Res. 41, 1070-1075

11 Brown, A.E., Schwartz, E.L., Dreyer, R.N. and Sartorelli, A.C. (1982) Biochim. Biophys. Acta 714, 217-225

12 Liu, C.-K., Schmied, R., Scher, W. and Waxman, S. (1981) Cancer Res. 41, 790-794

13 Hughes, R.C. (1976) Membrane Glycoproteins, Butterworths, London

14 Bosman, G.J.C.G.M., Boer, P. and Steyn-Parvé, E.P. (1982) Biochim. Biophys. Acta 696, 285-289
15 Ley, K.D. and Tobey, R.A. (1970) J. Cell. Biol. 47, 453-459

16 Gahmberg, C.G. and Andersson, L.C. (1977) J. Biol. Chem. $252,5888-5894$

17 Gahmberg, C.G. and Hakomori, S.-i. (1973) J. Biol. Chem. $248,4311-4317$

18 Weise, M.J. and Chan, L.-N.L. (1978) J. Biol. Chem. 253, 1892-1897

19 Fairbanks, G., Steck, Th.L. and Wallach, D.F.H. (1971) Biochemistry 10, 2606-2617

20 Schauer, R. (1978) Methods Enzymol. 50, 64-89

21 Reuter, G., Vliegenthart, J.F.G., Wember, M., Schauer, R., Howard, R.J. (1980) Biochem. Biophys. Res. Commun. 94, 567-572

22 Shukla, A.K. and Schauer, R. (1982) Hoppe Seyler's Z. Physiol. Chem. 363, 255-262

23 McClintock, P.R. and Papaconstantinou, J. (1974) Proc. Natl. Acad. Sci. U.S.A. 71, 4551-4555

24 Scher, W., Tsuei, D., Sassa, S., Price, P., Gabelman, N. and Friend, C. (1978) Proc. Natl. Acad. Sci. U.S.A. 75, 3851-3855

25 Buscher, H.-P., Casals-Steuzel, J. and Schauer, R. (1974) Eur. J. Biochem. 50, 71-82

26 Neuberger, A. and Ratcliffe, W.A. (1972) Biochem. J. 129 , 683-693

27 Bennett, G. and O'Shaughnessy, D. (1981) J. Cell Biol. 88, 1-15

28 Hager, D.A. and Burgess, R.R. (1980) Anal. Biochem. 109, 76-86

29 Terada, M., Fujiki, H., Marks, P.A. and Sugimura, T. (1979) Proc. Natl. Acad. Sci. U.S.A. 76, 6411-6414

30 Sarris, A.H. and Palade, G.E. (1979) J. Biol. Chem. 254, 6724-6731 